\title{
Shear behavior of DFDP-1 borehole samples from the Alpine Fault, New Zealand, under a wide range of experimental conditions
}

\author{
Matt J. Ikari · Sebastian Trütner · Brett M. Carpenter • \\ Achim J. Kopf
}

Received: 29 April 2014 / Accepted: 24 November 2014 / Published online: 9 January 2015

(C) The Author(s) 2015. This article is published with open access at Springerlink.com

\begin{abstract}
The Alpine Fault is a major plate-boundary fault zone that poses a major seismic hazard in southern New Zealand. The initial stage of the Deep Fault Drilling Project has provided sample material from the major lithological constituents of the Alpine Fault from two pilot boreholes. We use laboratory shearing experiments to show that the friction coefficient $\mu$ of fault-related rocks and their precursors varies between 0.38 and 0.80 depending on the lithology, presence of pore fluid, effective normal stress, and temperature. Under conditions appropriate for several kilometers depth on the Alpine Fault (100 MPa, $160{ }^{\circ} \mathrm{C}$, fluid-saturated), a gouge sample located very near to the principal slip zone exhibits $\mu=0.67$, which is high compared with other major fault zones targeted by scientific drilling, and suggests the capacity for large shear stresses at depth. A consistent observation is that every major lithological unit tested exhibits positive and negative values of friction velocity dependence. Critical nucleation patch lengths estimated using representative values of the friction velocity-dependent parameter $a-b$ and the critical slip distance $D_{c}$, combined with previously documented elastic properties of the wall rock, may be as low as $\sim 3 \mathrm{~m}$. This small value, consistent with a seismic moment $M_{o}=\sim 4 \times 10^{10}$ for an $M_{w}=\sim 1$ earthquake, suggests that events of this size or larger are expected to occur as ordinary earthquakes and that slow or transient slip events are unlikely in the approximate depth range of 3-7 km.
\end{abstract}

M. J. Ikari $(\bowtie) \cdot$ S. Trütner · A. J. Kopf

MARUM, Center for Marine Environmental Sciences,

University of Bremen, Bremen, Germany

e-mail: mikari@marum.de

B. M. Carpenter

Istituto Nazionale di Geofisica e Vulcanologia, Rome, Italy
Keywords Fault · Friction - Earthquake - Alpine Fault . Scientific drilling $\cdot$ ICDP $\cdot$ DFDP

\section{Introduction}

Assessing how major plate boundary faults fail, particularly as large earthquakes, requires analysis of how natural material from the fault zone and wall rock behave mechanically. Therefore, obtaining such samples has provided the impetus for large-scale scientific drilling projects (e.g., Ma et al. 2006; Tobin and Kinoshita 2006; Zoback et al. 2011). The Deep Fault Drilling Project (DFDP) was initiated in 2011 to investigate the Alpine Fault in New Zealand via coring, sampling, and wireline logging (Townend et al. 2009). The Alpine Fault is a highly appropriate target for study due to its status as a major plate boundary fault capable of large $\left(M_{w} \sim 8\right)$ earthquakes, as well as the inference that it may be nearing the end of its earthquake cycle (Sutherland et al. 2007; De Pascale and Langridge 2012).

Laboratory measurements of frictional properties are an essential component of studies targeting fault slip behavior. Measurements of frictional strength and how this strength changes as a function of slip velocity (friction velocity dependence) provide valuable information constraining the location and likelihood of earthquake slip nucleation. Simulating natural conditions on major fault zones at depths where large earthquakes nucleate (i.e., several $\mathrm{km}$ depth) is not always straightforward. However, it is a critical component of experimental studies because the frictional properties of fault material can be highly dependent on experimental conditions such as stress, temperature, and the presence of pore fluids (e.g., Handin 1969; Blanpied et al. 1998; Collettini et al. 2009; Carpenter et al. 2012; den Hartog and Spiers 2013; Ikari et al. 2013, 2014; Boulton 
et al. 2014). We present results of laboratory measurements of frictional strength and velocity-dependent friction at pressures and temperatures representing in situ conditions at several $\mathrm{km}$ depth using intact and disaggregated samples from the two pilot boreholes of a multi-phase scientific drilling project on the Alpine Fault. The data we present here are part of a larger effort to comprehensively quantify the mechanical behavior of the Alpine Fault and support other recent work with similar goals (e.g., Sutherland et al. 2012; Townend et al. 2013; Boulton et al. 2014; Carpenter et al. 2014; Ikari et al. 2014), as well as providing a foundation for further drilling during Phase 2 of DFDP.

\section{Geologic setting}

The Alpine Fault, South Island, New Zealand

The Alpine Fault forms part of the boundary between the Pacific Plate and the Australian Plate along the West coast of New Zealand's South Island (Fig. 1a). The fault is dextral-reverse and has accumulated $\sim 400-500 \mathrm{~km}$ of cumulative offset at a displacement rate of $\sim 23-27 \mathrm{~mm} /$ year over the past $\sim 50,000$ years, based on offset of geologic markers and radiocarbon dating (Cooper and Norris 1994; Norris and Cooper 2000; Sutherland et al. 2006). Major earthquakes $\left(M_{w}>7.0\right)$ are inferred to have occurred over the past 8,000 years with a recurrence of $\sim 260-400$ years (Bull 1996; Berryman et al. 2012). No large earthquake has occurred in the past 300 years, suggesting that a hazardous, large-magnitude earthquake on the Alpine Fault may be imminent (Sutherland et al. 2007, 2012; Townend et al. 2009, 2013). Geodetic measurements along the central segment of the fault indicate that the Alpine Fault is fully locked at depths of 5-8 $\mathrm{km}$ and partially locked up to $\sim 18 \mathrm{~km}$, and is loaded from below by the lower crust at a rate representing $50-70 \%$ of the plate convergence rate (Beavan et al. 1999, 2007; Norris and Cooper 2000; Wallace et al. 2007). The lack of measurable historic creep at the surface indicates that tectonic strain is balanced by earthquake slip (Beavan et al. 1999).

\section{Deep Fault Drilling Project and sample description}

The Alpine Fault was chosen for scientific drilling because it is nearing the end of its earthquake cycle, high exhumation rates that have resulted in well-exposed outcrops of representative lithologies from depth, well-constrained Quaternary slip rates, the presence of an extensive geophysical monitoring network, and a fault dip of $\sim 45^{\circ}$ which allows penetration by vertical boreholes (Townend et al. 2009). Drilling on the central portion of the Alpine Fault commenced as part of the Deep Fault Drilling
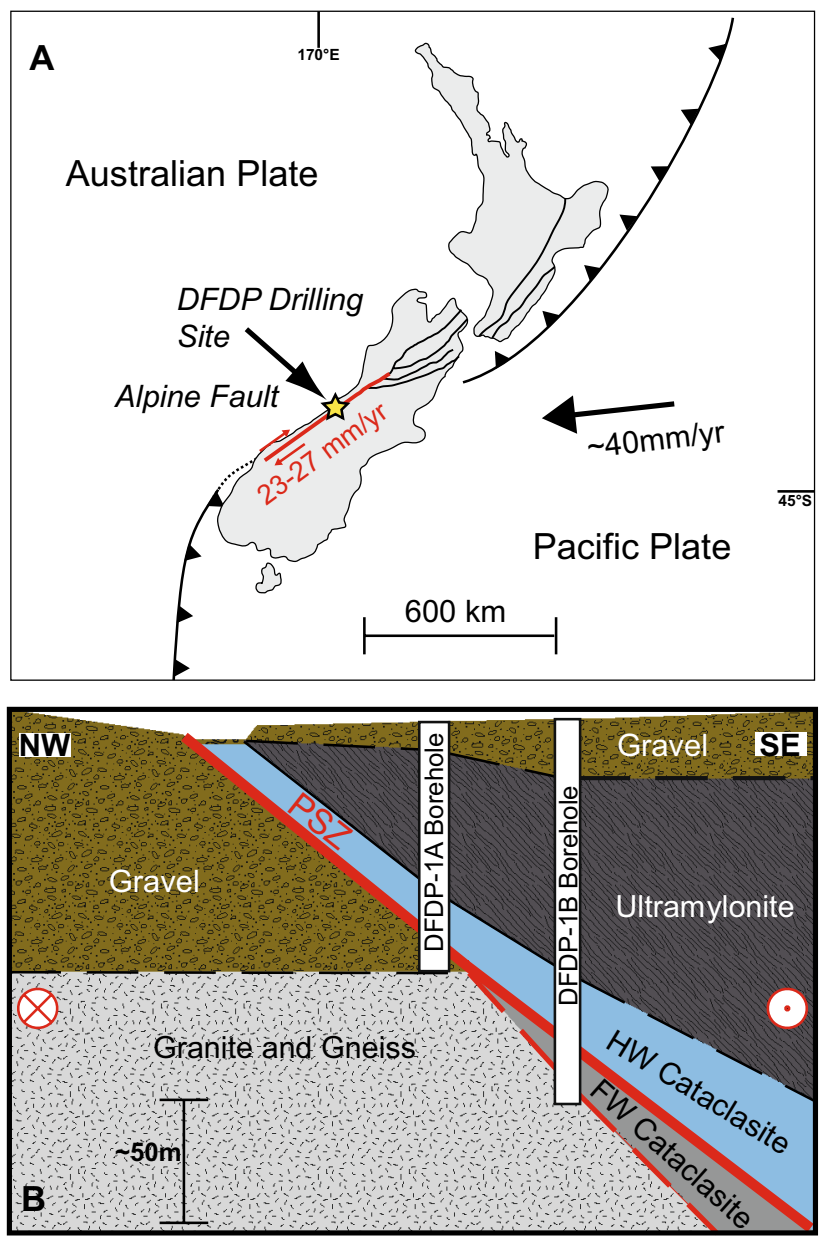

Fig. 1 a Map of the New Zealand area. Star indicates location of DFDP drilling. b Geologic cross-section showing DFDP-1A and DFDP-1B boreholes (modified from Sutherland et al. 2012)

Project (DFDP) within the framework of the International Continental Scientific Drilling Project (ICDP). The initial phase of the project resulted in two pilot boreholes located $80 \mathrm{~m}$ apart: DFDP-1A drilled to $96-\mathrm{m}$ depth, and DFDP-1B drilled to 151-m depth (Fig. 1b). A deeper borehole with a target depth of $\sim 1,500 \mathrm{~m}$ is planned for the second phase of the project, DFDP-2. The hanging wall consists of five major lithologies: dark-gray highly fractured ultramylonite, laminated brown-green-black ultramylonite, foliated and unfoliated greenish-gray cataclasite, and gouge (Toy et al. 2014). Both boreholes successfully penetrated the fault zone proper, which is identified in recovered drill cores as a $\mathrm{cm}$-scale package of fine-grained, clay-rich gouge interpreted to be a principal slip zone (PSZ) (Sutherland et al. 2012; Townend et al. 2013). The PSZ in borehole DFDP-1A is $\sim 3 \mathrm{~cm}$ thick and located at $\sim 90.6-\mathrm{m}$ depth, under which Quaternary fluvial gravels were recovered as the footwall. In DFDP-1B, two PSZs were identified (Toy et al. 2014). The main (upper) 
Table 1 Sample and experiment details

\begin{tabular}{|c|c|c|c|c|c|c|c|}
\hline Experiment & Sample & $\begin{array}{l}\text { Depth in } \\
\text { core }(m)\end{array}$ & Lithology & Sample state & Pore fluid & $\begin{array}{l}\text { Effective normal } \\
\text { stress (MPa) }\end{array}$ & $\begin{array}{l}\text { Temperature } \\
\left({ }^{\circ} \mathrm{C}\right)\end{array}$ \\
\hline HDS72 & DFDP 1A Run57 & 77.8 & Ultramylonite & Disaggregated (mm-scale) & Dry & 50 & 75 \\
\hline HDS79 & DFDP 1A Run57 & 77.8 & Ultramylonite & Disaggregated (mm-scale) & Dry & 50 & 150 \\
\hline HDS83 & DFDP 1A Run57 & 77.8 & Ultramylonite & Disaggregated (mm-scale) & Dry & 50 & 225 \\
\hline HDS75 & DFDP 1A Run57 & 77.8 & Ultramylonite & Disaggregated (mm-scale) & Dry & 100 & 200 \\
\hline HDS68 & DFDP 1A Run57 & 77.8 & Ultramylonite & Disaggregated (mm-scale) & DI water & 50 & 22 \\
\hline HDS77 & DFDP 1A Run57 & 77.8 & Ultramylonite & Disaggregated (mm-scale) & DI water & 50 & 75 \\
\hline HDS69 & DFDP 1A Run57 & 77.8 & Ultramylonite & Disaggregated (mm-scale) & DI water & 100 & 22 \\
\hline HDS70 & DFDP 1A Run57 & 77.8 & Ultramylonite & Disaggregated (mm-scale) & DI water & 150 & 22 \\
\hline HDS100 & DFDP 1A Run 55 & 76.2 & Ultramylonite & Powdered $(<250 \mu \mathrm{m})$ & DI water & 100 & 160 \\
\hline HDS97 & DFDP 1A Run57 & 77.8 & Ultramylonite & Disaggregated (mm-scale) & DI water & 100 & 160 \\
\hline HDS96 & DFDP 1A Run65 & 88.6 & Cataclasite & Intact cylinder & DI water & 100 & 160 \\
\hline HDS105 & DFDP 1A Run 66 & 90.5 & Gouge near PSZ & Intact cylinder & DI water & 100 & 160 \\
\hline HDS98 & DFDP 1A Run 66 & 91.0 & Fluvial gravel & Powdered $(<250 \mu \mathrm{m})$ & DI water & 100 & 160 \\
\hline HDS101 & DFDP 1B Run 30CC & 96.4 & Ultramylonite & Powdered $(<250 \mu \mathrm{m})$ & DI water & 100 & 160 \\
\hline HDS102 & DFDP 1B Run 37CC & 106.6 & Protocataclasite & Powdered $(<250 \mu \mathrm{m})$ & DI water & 100 & 160 \\
\hline HDS103 & DFDP 1B Run 65 & 136.9 & Granitoid cataclasite & Intact cylinder & DI water & 100 & 160 \\
\hline
\end{tabular}

PSZ is $\sim 20 \mathrm{~cm}$ thick and located within green cataclasites at a depth of $\sim 128 \mathrm{~m}$, as measured in the recovered core. The second PSZ is located at $144-\mathrm{m}$ depth; it is yet to be determined which PSZ was most recently active. The footwall in the DFDP-1B borehole consists of granitoid cataclasites underlain by gneisses. From Borehole 1A, we tested two hanging wall ultramylonite samples, a poorly indurated gouge sample from $30 \mathrm{~cm}$ above the PSZ, and one sample of footwall gravel (Table 1). We emphasize that the gouge sample is located near but not within the zone interpreted as the PSZ, rather it is part of a larger zone of cataclasite-derived gouge. From Borehole 1B, we tested one ultramylonite sample and one sample of (proto-) cataclasite from the hanging wall and one granitoid cataclasite sample from below the first PSZ but above the second PSZ (Table 1).

\section{Experimental methods}

Shearing experiments were conducted in a single-direct shear apparatus under controlled normal stresses up to $150 \mathrm{MPa}$, temperatures up to $225^{\circ} \mathrm{C}$, and with constant, monitored pore fluid pressures. The sample cell consists of a cylindrical volume (diameter $63 \mathrm{~mm}$, height $\sim 30-50 \mathrm{~mm}$ ) within two hardened steel blocks. The top face of the sample (not the forcing block) is loaded vertically, and the lower block is displaced relative to the upper block using a near-frictionless roller mechanism at a controlled displacement rate, inducing shear perpendicular to the cylinder axis (Fig. 2). Although the total sample height is $\sim 3 \mathrm{~cm}$, the deformation is planar and thus simulates localized shear, although the actual shear surface of the sample may be slightly irregular. O-ring seals located between the two sample cell blocks, and between the upper cell and driving piston, confine deionised water pore fluids. Isolated ports in the lower block allow the pore pressure in at the sample bottom (backpressure) and also along the shear surface to be monitored separately (Fig. 2, inset). Pore fluid pressures were kept low ( 500-600 kPa) by manually draining the sample with an external vent so that the applied normal stress $\sigma_{n}$ may be considered to be the effective normal stress $\sigma_{n}^{\prime}$. The temperature is constantly monitored in two locations: within the oven external to the sample cell and via a thermistor in one of the ports in the lower cell in contact with the pore fluid.

We conducted two sets of experiments. In the first set, we used one sample of mylonite, obtained from $77.8 \mathrm{~m}$ depth in the DFDP-1A borehole. This sample is highly friable and was thus tested as disaggregated, mm-scale rock chips similar to borehole cuttings. For these experiments, only external (oven) temperature monitoring and, for tests with pore fluid, only backpressure fluid monitoring were available. This set of experiments was done using one sample in order to explore the effect of pressure and temperature, as well as the presence or absence of pore fluid on frictional behavior. In the second set of experiments, we used a selection of samples from both the DFDP-1A and DFDP-1B boreholes. These were either tested as disaggregated rock chips, or further ground to a maximum grain size of $250 \mu \mathrm{m}$. When 
Fig. 2 Schematic illustration of the heated single-direct shear device

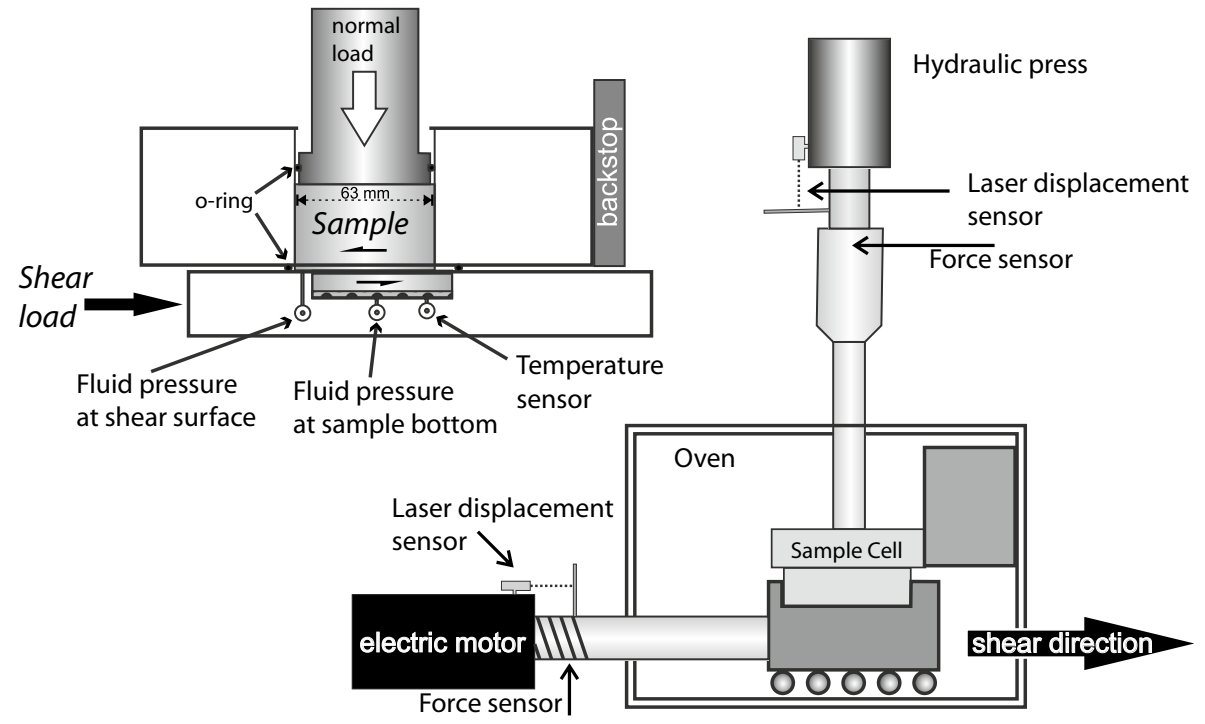

$a-b=\frac{\Delta \mu_{s s}}{\ln \left(V / V_{0}\right)}$

possible, some samples were tested as intact rock cylinders aligned perpendicular to the core axis. These samples were either drilled or otherwise carefully sculpted from an original whole-round core diameter of $83 \mathrm{~mm}$ down to $63 \mathrm{~mm}$ and were saturated with deionised water under a vacuum overnight. For this set of experiments, all samples were sheared with the presence of pore fluid at $100 \mathrm{MPa}$ effective normal stress and $160{ }^{\circ} \mathrm{C}$ as monitored by pore fluid temperature, in order to simulate realistic in situ conditions at several $\mathrm{km}$ depth. This set of experiments facilitates comparison between samples from the major lithologic units in the DFDP-1 boreholes at consistent pressure, temperature, and fluid saturation conditions.

We sheared the samples at a constant velocity of $10 \mu \mathrm{m} / \mathrm{s}$ for up to $12 \mathrm{~mm}$ in order to measure the steady-state shear strength $\tau$ (Fig. 3). Most samples achieved steady-state (i.e., residual) strength by 9 -mm displacement; however, some samples exhibited long-term strain hardening. In these cases, residual strength was measured at 9-mm displacement to facilitate comparison between samples. Most samples did not exhibit a significant peak in strength, but rather a gradual increase to a residual value. We calculate the coefficient of sliding friction $(\mu)$ as:

$\mu=\frac{\tau}{\sigma_{n}^{\prime}}$

(Handin 1969) assuming that cohesion is negligible in our disaggregated samples or is lost after significant displacement in intact samples. After $~ 9-$ to 12-mm displacement, velocity-stepping tests were initiated in which the shear velocity was increased in discrete threefold (half order of magnitude) velocity steps in the range $0.1-30 \mu \mathrm{m} / \mathrm{s}$. From these tests, we quantify the rate dependence of friction with the parameter $a-b$ : where $\Delta \mu_{s s}$ is the change in steady-state coefficient of friction upon an instantaneous change in sliding velocity from $V_{0}$ to $V$ (e.g., Marone 1998; Fig. 3). Materials that exhibit positive values of $a-b$, or velocity-strengthening behavior, are expected to slide stably and therefore would be unable to host earthquake nucleation, and also resist earthquake propagation. Negative values of $a-b$, or velocity-weakening behavior, are required for frictional instability that results in earthquake nucleation, depending also on the elastic conditions in the fault zone (Scholz 1998, 2002). In the laboratory, a velocity-weakening material sheared in a sufficiently compliant testing apparatus may result in stickslip-type instability, which is considered analogous to the earthquake cycle (e.g., Brace and Byerlee 1966).

Equation 2 is a reduced form of phenomenological constitutive law developed by Dieterich $(1979,1981)$ and is known as rate- and state-dependent friction:

$\mu=\mu_{0}+a \ln \left(\frac{V}{V_{0}}\right)+b_{1} \ln \left(\frac{V_{0} \Theta_{1}}{D_{c 1}}\right)+b_{2} \ln \left(\frac{V_{0} \Theta_{2}}{D_{c 2}}\right)$

$\frac{\mathrm{d} \Theta_{i}}{\mathrm{~d} t}=1-\frac{V \Theta_{i}}{D_{c i}}, \quad i=1,2$

where $a, b_{1}$, and $b_{2}$ are empirically derived constants (unitless), $\Theta_{1}$ and $\Theta_{2}$ are the state variables which represent the time over which grain-scale asperity contacts are renewed (Dieterich and Kilgore 1994) or necessary to reach a critical granular porosity during shear (e.g., Marone and Kilgore 1993). The critical slip distances $D_{c 1}$ and $D_{c 2}$ are the displacements that correspond with the state variables and 
Fig. 3 a Example of experimental data, indicating steadystate friction measurement and velocity-stepping tests. Box indicates data shown in $\mathbf{b}$ as an example of a frictional response to a velocity step. Data are overlain by an inverse model
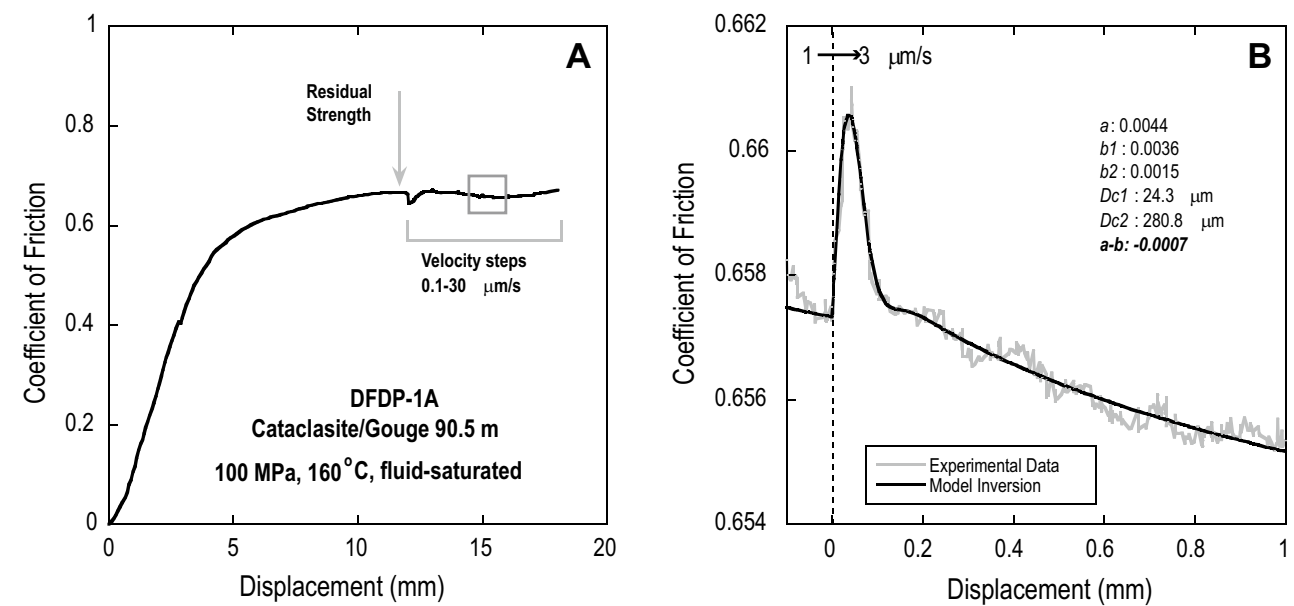

represent displacement necessary to re-establish a steadystate shearing condition (Fig. 3b).

We use an iterative least-squares inversion method to extract the rate-dependent friction parameter $a-b$ as well as the individual parameters $a, b_{1}, b_{2}, D_{c 1}$, and $D_{c 2}$ (Reinen and Weeks 1993; Saffer and Marone 2003; Ikari et al. 2009). In many cases, the data are well described with only one state variable; in such cases, Eqs. 3 and 4 are simplified by setting $b_{2}=0$. However, in some cases, employing two state variables $\left(\Theta_{1}\right.$ and $\left.\Theta_{2}\right)$ better describes friction data from velocity step tests compared to a single state variable model. When two state variables are employed, we define $b=b_{1}+b_{2}$ (thus, $a-b=a-\Sigma b$ ). The physical mechanisms which dictate the number of state variables, however, are not well known (e.g., Blanpied et al. 1998).

\section{Results}

DFDP-1A mylonite (77.8 $\mathrm{m}$ depth)

Results of friction experiments for the mylonite sample show that under nominally dry conditions and a constant normal stress of $50 \mathrm{MPa}$, friction increases with temperature from $\mu=0.57$ at $75{ }^{\circ} \mathrm{C}$ to $\mu=0.80$ at $225{ }^{\circ} \mathrm{C}$ (Fig. 4). The presence of pore water tends to weaken samples, as evidenced in two cases: (1) at $50 \mathrm{MPa}$ and $75{ }^{\circ} \mathrm{C}$, where $\mu=0.57$ dry and $\mu=0.46$ wet, and (2) at $100 \mathrm{MPa}$, where $\mu=0.55$, dry at $200^{\circ} \mathrm{C}$ and $\mu=0.43$ wet, at $160{ }^{\circ} \mathrm{C}$. In contrast with the dry samples, increasing temperature in wet samples tends to decrease their frictional strength (Fig. 4). Under fluid-saturated conditions and at room temperature $\left(22{ }^{\circ} \mathrm{C}\right.$ ), we find that increasing normal stress in the range 50-150 MPa has little effect on friction $(\mu=0.60-0.62)$.

For the mylonite samples, we observe mostly velocity-strengthening behavior, but also several instances of velocity-weakening friction (Fig. 5; Table 2). For dry

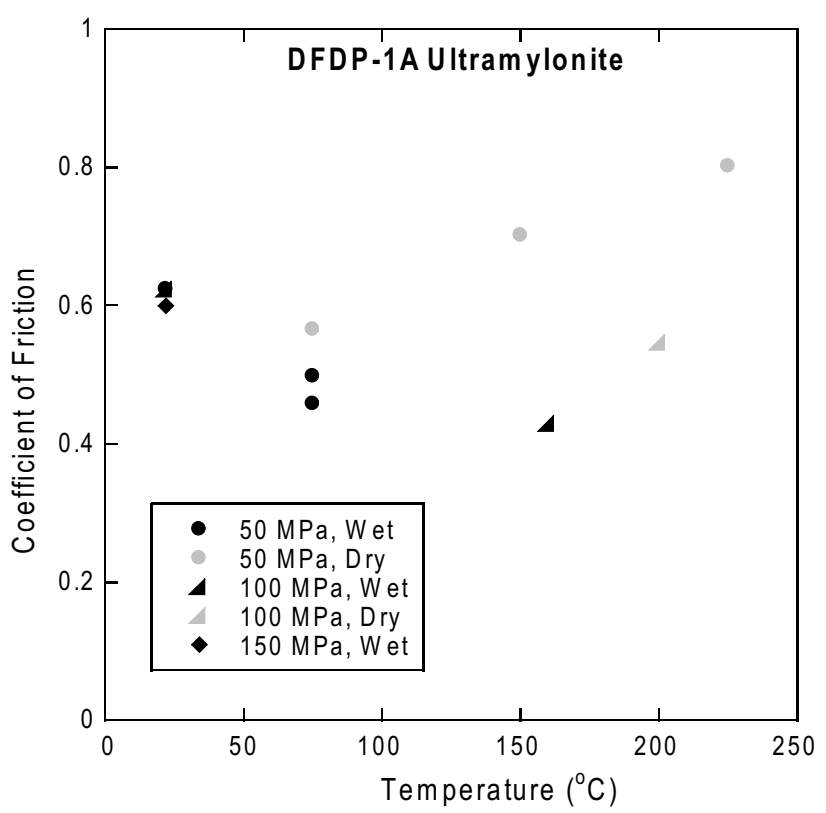

Fig. 4 Coefficient of friction as a function of temperature for an ultramylonite sample from DFDPD-1A comparing wet and dry samples at a range of effective normal stresses

mylonite samples at $50 \mathrm{MPa}, a-b$ values are positive at $75^{\circ} \mathrm{C}(a-b=\sim 0.001-0.006)$, but at elevated temperature $\left(150\right.$ and $\left.225{ }^{\circ} \mathrm{C}\right)$ velocity weakening $(a-b=<-0.003)$ and instances of stick-slip are observed. Fluid-saturated samples at room temperature show velocity strengthening $(a-b=\sim 0.001-0.005)$ at 50 and $100 \mathrm{MPa}$, but velocity neutral to weakening behavior at $150 \mathrm{MPa}$ effective normal stress $(a-b=0$ to $\sim-0.001)$. Values of $a-b$ are mostly positive for wet and dry samples at the same effective stress and similar temperatures (e.g., wet and dry samples at $50 \mathrm{MPa}$ and $75^{\circ} \mathrm{C}$, and wet and dry samples at $100 \mathrm{MPa}$ and $160-200{ }^{\circ} \mathrm{C}$ ), but a few instances of velocity weakening are observed for wet samples. No clear dependence of 


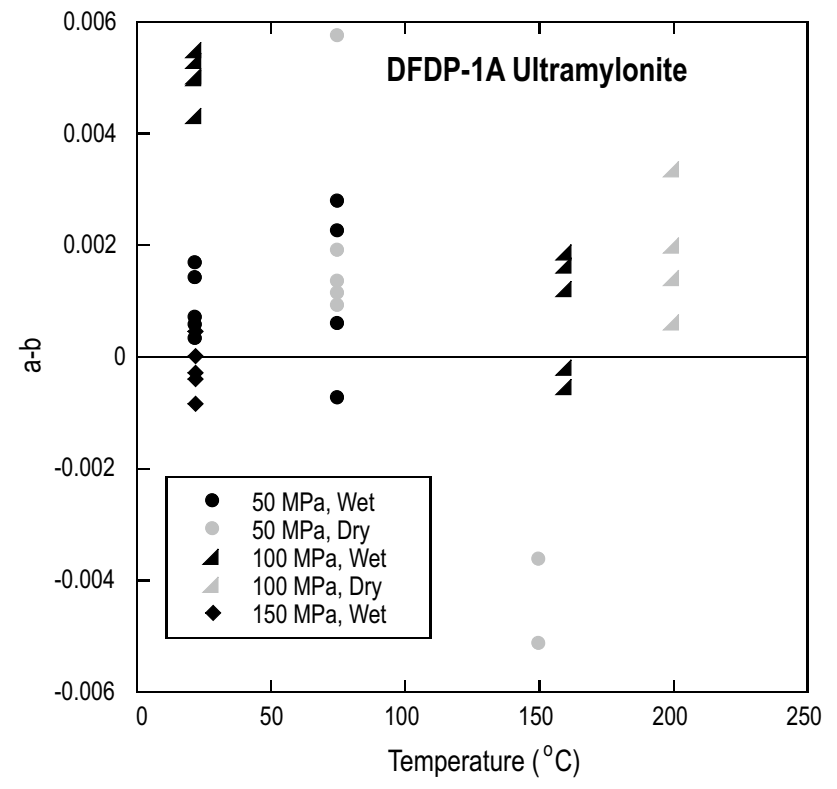

Fig. 5 Velocity-dependent friction parameter $a-b$ as a function of temperature for an ultramylonite sample from DFDPD-1A comparing wet and dry samples at a range of effective normal stresses

$a-b$ on sliding velocity could be distinguished outside of the data scatter.

\section{DFDP-1A and DFDP-1B core samples at elevated P-T}

At $100 \mathrm{MPa}, 160{ }^{\circ} \mathrm{C}$ and in the presence of pore fluid, samples from Borehole 1A show a large range in strength, and a simple relationship with lithology or sample state (disaggregated vs. intact) is not apparent. The two tested ultramylonite samples exhibit residual $\mu$ of 0.43 and 0.73 (Fig. 6). The coefficient of friction of the shallower cataclasite sample is $\mu=0.51$, whereas the gouge sample near the PSZ exhibited $\mu=0.67$. The footwall gravel sample was the weakest tested from either borehole, with $\mu=0.37$. For the DFDP-1B borehole, friction coefficients were more consistent, ranging from $\mu=0.44$ to 0.49 for the three different lithologies (ultramylonite, proto-cataclasite, granitoid cataclasite). The ultramylonite sample from Borehole 1B was the only sample that exhibited a slight peak, at $\mu=0.45$ (residual $\mu=0.44)$.

For both boreholes, $a-b$ values range between $\sim-0.001$ and 0.002 (Fig. 7; Table 3). All samples exhibited both velocity-weakening and velocity-strengthening behaviors, except the shallower cataclasite sample from Borehole $1 \mathrm{~A}$, which was exclusively velocity strengthening. Stickslip instability was observed for two samples: the footwall gravel in Borehole 1A and the proto-cataclasite in Borehole 1B. In both cases, stick-slip occurred at slip velocities of $1 \mu \mathrm{m} / \mathrm{s}$ or lower. In a similar fashion to coefficient of friction values, $a-b$ does not clearly correlate with variations in lithology, physical sample state, or slip velocity.

\section{Discussion}

Observed frictional behavior

In general, our experimental results compare favorably with other recent work using Alpine Fault DFDP core samples. For example, Ikari et al. (2014) measured friction coefficients of $0.56-0.65$ for dry ultramylonite samples at $\sigma_{n}^{\prime}=40-100 \mathrm{MPa}$; which compares favorably with our values of $\mu=0.55-0.7$ at 50-150 MPa, even though our experiments were conducted at higher temperatures. They also observed that water saturation tends to reduce friction coefficients for samples from Borehole 1A, which we also observe (Fig. 4), and to promote velocity-strengthening behavior. While an increase in $a-b$ for wet samples is not as clear in our ultramylonite dataset, we do observe that only dry samples exhibit stick-slip behavior, while wet samples do not, suggesting a stabilizing effect of pore fluid. Using disaggregated samples of the PSZ from Borehole 1A, Boulton et al. (2014) measured a friction coefficient of 0.62 at $94 \mathrm{MPa}$ and $210{ }^{\circ} \mathrm{C}$, which matches our measured value of 0.67 at $100 \mathrm{MPa}$ and $160{ }^{\circ} \mathrm{C}$ for the gouge sample adjacent to the PSZ. They also reported strictly positive $a-b$ values for the 1A-PSZ at lower pressure and temperature $\left(<62 \mathrm{MPa}, \leq 140{ }^{\circ} \mathrm{C}\right)$ and velocity weakening at higher pressure and temperature $\left(94 \mathrm{MPa}, 210{ }^{\circ} \mathrm{C}\right)$. This is also consistent with our measurements, considering that we observe both velocity strengthening and velocity weakening at conditions within this range.

The strength of the gouge sample near the PSZ of $\mu=0.67$ is notably high in comparison with drilling samples from other major fault zones tested at comparable effective normal stresses, for example the Nankai Trough offshore Japan $(\mu<0.4$ at $80-120 \mathrm{MPa}$, Saffer et al. 2012) and the San Andreas Fault near Parkfield, California $(\mu=0.1-0.15$ at 40-200 MPa, Lockner et al. 2011; Carpenter et al. 2012). These studies also reported only velocity-strengthening behavior; however, their experiments were conducted at room temperature. It has been demonstrated that elevated temperatures can cause both an increase in friction (to $\mu \geq 0.6$ ) and velocity-weakening behavior to occur in materials that are velocity strengthening at room temperature, for both clay-rich and clay-poor samples (e.g., Blanpied et al. 1998; den Hartog and Spiers 2013). We suggest that this is the case for the Alpine Fault, where lower friction $(\mu=0.45)$ and velocity-strengthening behavior has been reported at low temperatures (Ikari et al. 2014) but higher friction and velocity-weakening behavior is common at higher pressure and temperature (Boulton et al. 2014). 


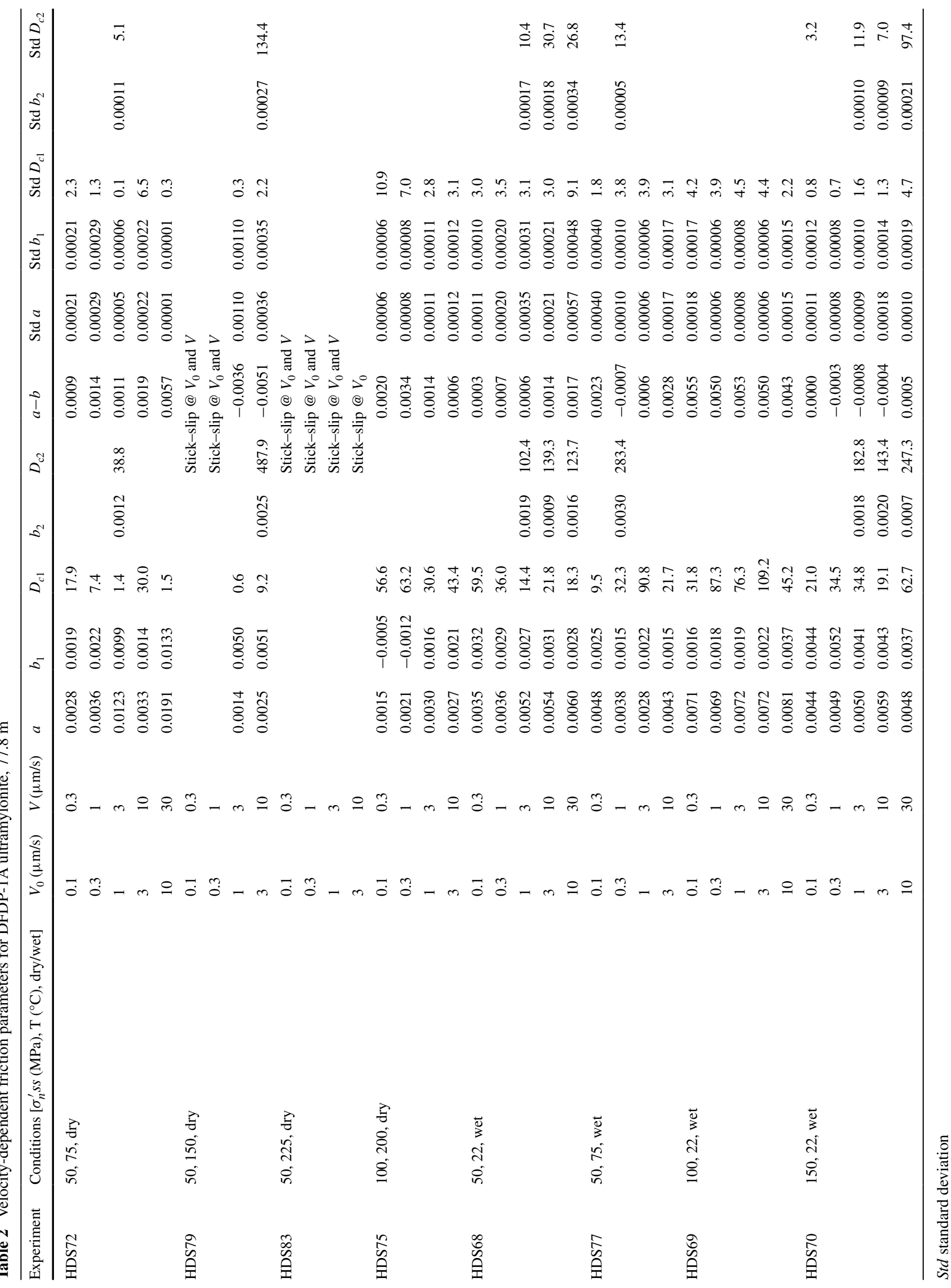




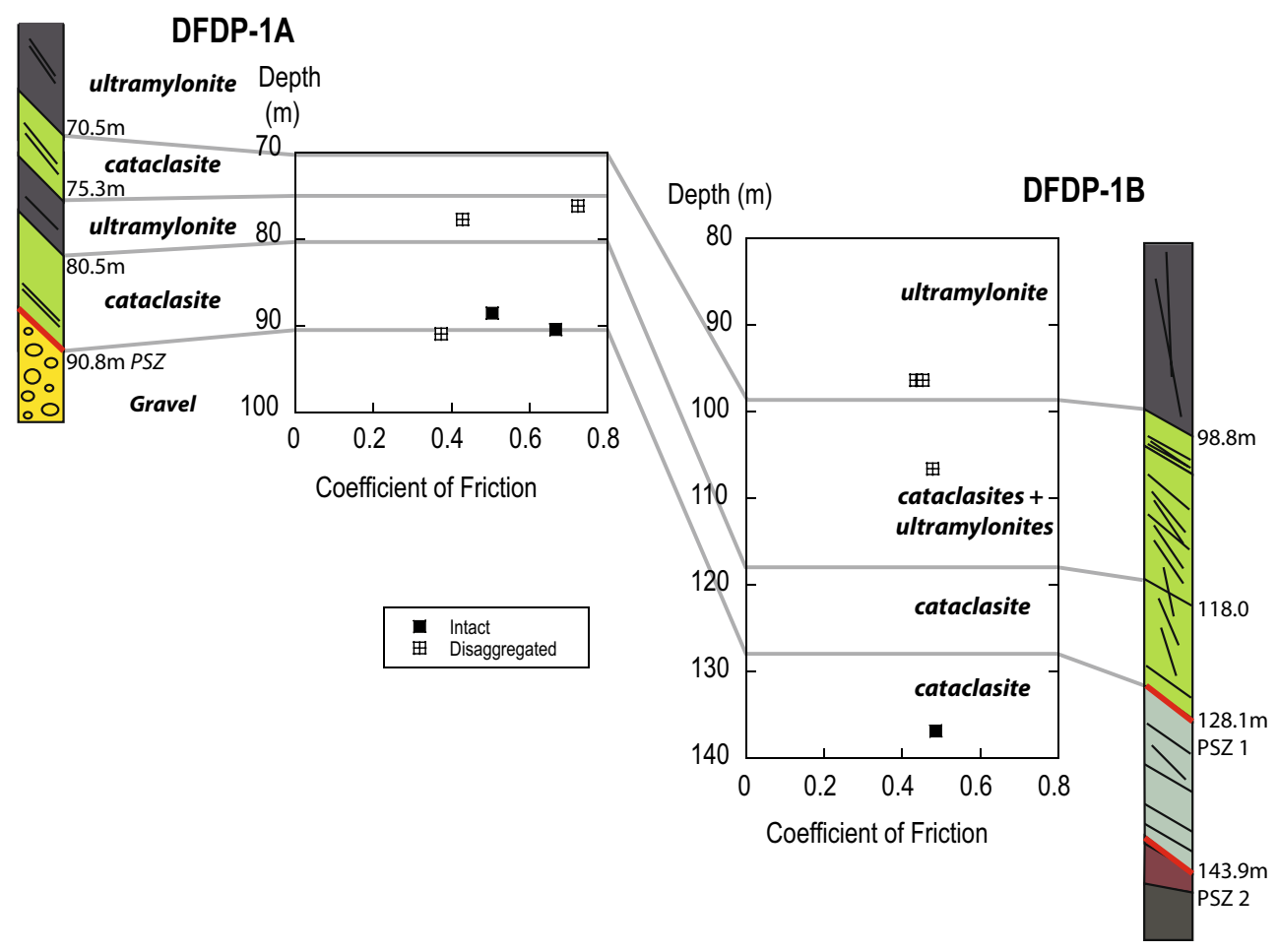

Fig. 6 Coefficient of friction with recovery depth for samples of major lithologic units from DFDP Boreholes 1A and 1B. All experiments in this figure were conducted water saturated at $100 \mathrm{MPa}$ and $160{ }^{\circ} \mathrm{C}$

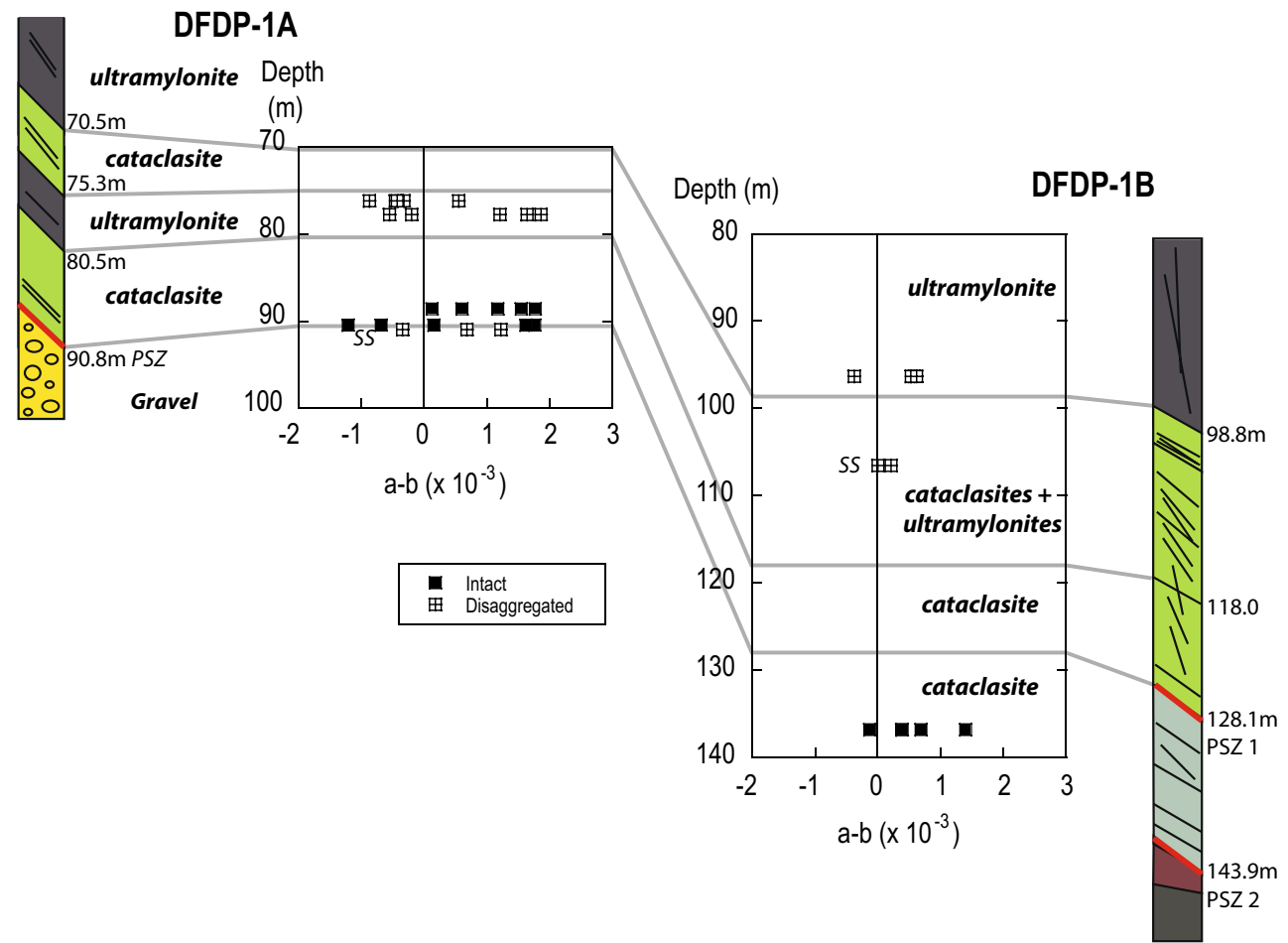

Fig. 7 Velocity-dependent friction parameter $a-b$ with recovery depth for samples of major lithologic units from DFDP Boreholes $1 \mathrm{~A}$ and $1 \mathrm{~B}$. All experiments in this figure were conducted water satu- rated at $100 \mathrm{MPa}$ and $160{ }^{\circ} \mathrm{C}$. SS indicates stick-slip behavior, for the gravel in Borehole 1A and the (proto) cataclasites at $106.6 \mathrm{~m}$ in Borehole $1 \mathrm{~B}$ 


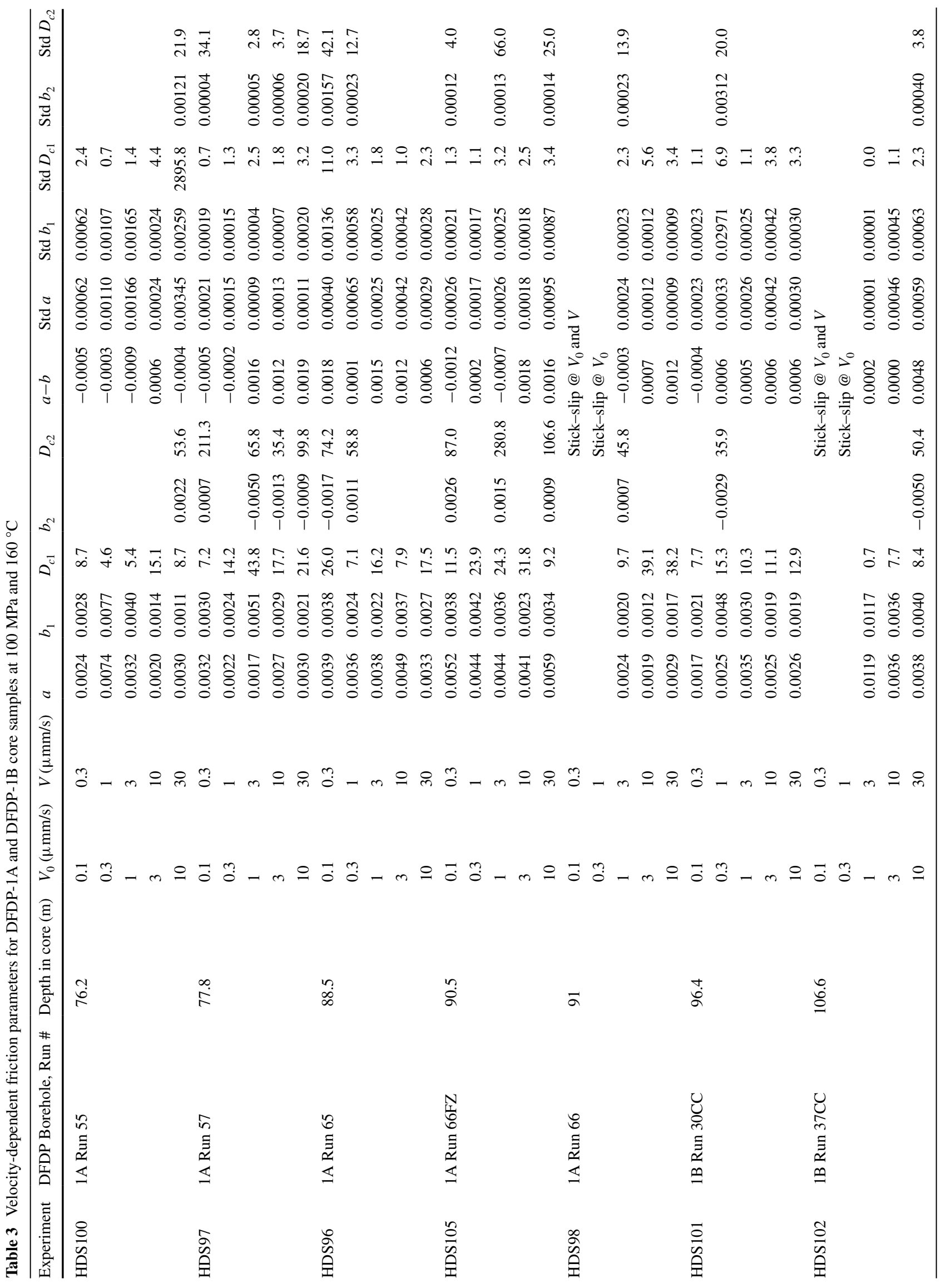




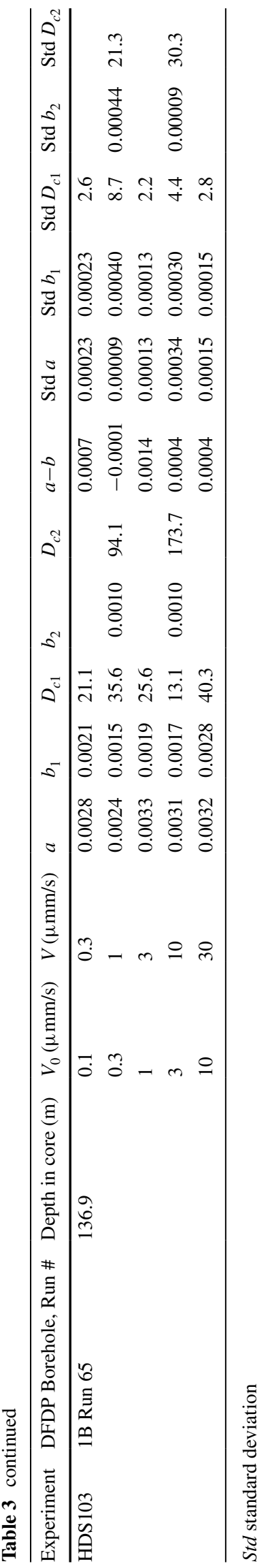

We do not observe a significant difference in frictional properties between the three samples tested as intact cylinders compared to disaggregated samples (Figs. 6, 7) which is somewhat surprising considering that rock fabric can have a significant effect depending on the intensity of the foliation and whether phyllosilicate minerals are present (e.g., Collettini et al. 2009; Ikari et al. 2011). For our samples, the predominant rock fabric dips $35^{\circ}-65^{\circ}$ based on visual core description, consistent with earlier field observations indicating that the foliation of Alpine Fault-related rocks dips $\sim 40^{\circ}-50^{\circ}$ (Sibson et al. 1981). Therefore, we suggest that the fabric is unfavorably oriented for weakening with respect to the shear plane (which is perpendicular to the core axis in our experiments) and thus does not play role in these experiments. Furthermore, fabric and cementation that may have developed in situ at shallow depths may be lost when the samples are subjected to higher pressure and temperature.

Implications for the slip behavior of the Alpine Fault

The conditions we used for our selection of core samples, $100 \mathrm{MPa}$ and $160{ }^{\circ} \mathrm{C}$, correspond to a depth range of $\sim 4-7 \mathrm{~km}$, assuming an effective stress gradient of $15-20 \mathrm{MPa} / \mathrm{km}$ and a temperature gradient of $\sim 23-40{ }^{\circ} \mathrm{C} /$ $\mathrm{km}$. However, larger temperature gradients on the Alpine Fault may also be appropriate due to rapid uplift (e.g., Koons 1987), consistent with borehole temperature measurements indicating a gradient of $\sim 60{ }^{\circ} \mathrm{C} / \mathrm{km}$, at least near the surface (Sutherland et al. 2012). In this case, the shallow end of our applicable depth range may be $2.5-3 \mathrm{~km}$. Therefore, our observations of partially velocity-weakening behavior for all major Alpine Fault lithologies suggest that, at in situ conditions representative of a few $\mathrm{km}$ depth, unstable slip should be expected. This is consistent with earthquake hypocenters which are distributed from 8 to $12 \mathrm{~km}$ up to the near surface on the Alpine Fault (Leitner et al. 2001) and GPS measurements which indicate that the central Alpine Fault is not creeping and the upper $5-8 \mathrm{~km}$ is likely locked and accumulating strain (Beavan et al. 1999). This evidence suggests that the Alpine Fault is frictionally unstable throughout the shallow crust, a unique characteristic that distinguishes the Alpine Fault from other plate boundary fault zones which typically exhibit a creeping "aseismic" zone in the shallowest few km (e.g., Byrne et al. 1988; Marone and Scholz 1988; Hyndman et al. 1997). Rapid exhumation of high-grade metamorphic fault rock is an attractive explanation (Koons 1987; Little et al. 2005).

The relatively high strength of the Alpine Fault, based on our sample near the PSZ combined with other high pressure-temperature data using PSZ material (Boulton et al. 2014), suggests that high resolved shear stresses may accumulate on the fault before failure. Because we also 
observe friction coefficients as low as $\mu=0.43$ (excluding the gravel, which is not expected to be present at greater depth), it is possible that the Alpine Fault may fail in other lithologic units. However, our observations of velocity weakening in most of our samples suggest that earthquake nucleation is also possible in each of the major lithological units. Earthquake nucleation requires not only velocityweakening frictional behavior but also sufficient compliance in the wall rocks surrounding the fault zone (Scholz 1998, 2002). This is formulated as the critical stiffness criterion, in which the stiffness of the fault surroundings $K$ (stress/length) must be lower than a critical value $K_{c}$ defined by frictional properties and the effective normal stress:

$K<K_{c}=\frac{-(a-b) \sigma_{n}^{\prime}}{D_{c}}$

From our experimental data, we may calculate the critical value $K_{c}$ necessary for slip instability. If we consider our gouge sample from the DFDP-1A borehole near the PSZ to be most appropriate for the fault zone, appropriate minimum values are $a-b=-0.001$ and $D_{c}=10 \mu \mathrm{m}$ (considering $D_{c 1}$, see Table 3). For an effective normal stress of $100 \mathrm{MPa}, K_{c}$ is then approximately $0.01 \mathrm{MPa} / \mu \mathrm{m}$, or $10 \mathrm{GPa} / \mathrm{m}$. This value, in conjunction with the Young's modulus $E$ and Poisson's Ratio $v$, define a minimum patch length $2 L_{c}$ :

$2 L_{c}=\frac{E}{\left(1-v^{2}\right) K_{c}}$

(where $L_{c}$ is the patch half-length) for the nucleation of unstable slip, whereas slip nucleating on patches smaller than $2 L_{c}$ will be stable (Scholz 1998, 2002).

We use laboratory measurements of elastic properties on DFDP-1A and DFDP-1B core samples (Carpenter et al. 2014) of $E=30 \mathrm{GPa}$ and $v=0.3$ for hanging wall cataclasite samples at isotropic confining pressures of $63.5 \mathrm{MPa}$, which results in a critical patch length $2 L_{c}=3.3 \mathrm{~m}$. This is a very small value which corresponds to a seismic moment $M_{o}=\sim 4 \times 10^{10} \mathrm{Nm}$ based on the scaling relation $M_{o}=10^{9}\left(2 L_{c}\right)^{3}$ (Ohnaka 2000), or an earthquake of moment magnitude $\sim 1$. If values of $E=16 \mathrm{GPa}$ and $v=0.37$ are used, which were obtained for a cataclasite very near the PSZ at $\sim 90 \mathrm{~m}$ depth in Borehole $1 \mathrm{~A}$, the calculated value of $2 L_{c}$ decreases further to $\sim 2 \mathrm{~m}$. The small critical nucleation patch size is significant because it suggests that unstable slip on the Alpine Fault is easily achieved, without requiring a long phase of quasi-stable slip during nucleation.

It also suggests that any slip event on the fault is likely to be an earthquake, rather than occurring as various types of discrete slow or transient slip events (Ide et al. 2007; Peng and Gomberg 2010). Ide et al. (2007) showed that the seismic moment (and moment magnitude) for slow earthquakes of all forms scales consistently with their characteristic duration in a manner that clearly distinguishes them from ordinary earthquakes. This was demonstrated for slow events with $M_{o}$ ranging from $\sim 10^{11}$ to $10^{21} \mathrm{Nm}$ and $M_{w}$ from $\sim 1$ to 8 . However, they also show that the relations for slow and normal earthquakes converge at the low end of the scale, which coincides with the $M_{o}$ and $M_{w}$ calculated for a minimum nucleation patch length on the Alpine Fault. Because our frictional and elastic property estimates for the Alpine Fault indicate that any slip event with $M_{o}>\sim 4 \times 10^{10}$ and $M_{w}>\sim 1$ are likely to be unstable, we suggest that slow slip events should not be expected in the depth range of $\sim 3-7 \mathrm{~km}$ and that any nucleating slip event will result in an ordinary earthquake. Slow fault slip has also been recently observed on the Alpine Fault in the form of tectonic tremor (Wech et al. 2012) and low-frequency earthquakes (Chamberlain et al. 2014), but these events are located deeper than $20-25 \mathrm{~km}$, well below the inferred lower limit of the seismogenic zone on the Alpine Fault.

\section{Conclusions}

Based on laboratory shearing experiments using a sample of ultramylonite from borehole DFDP-1A, we show that the friction coefficient $\mu$ and the velocity dependence of friction, $a-b$, can vary substantially depending on the presence of pore fluid, effective normal stress, and temperature. Under conditions appropriate for several $\mathrm{km}$ depth on the Alpine Fault (100 MPa, $160{ }^{\circ} \mathrm{C}$, fluid-saturated), the friction coefficient $\mu$ varies between 0.43 and 0.73 , with a gouge sample located very near to the principal slip zone (PSZ) exhibiting $\mu=0.67$. This relatively high value suggests the capacity for large shear stresses at depth and that slip may also occur in other lithological units, e.g., ultramylonite or cataclasite, where the friction is lower. Observations of velocity-weakening friction in all lithologies tested from both boreholes suggest that earthquake nucleation is possible regardless of where the slip nucleates. Calculations using experimentally obtained values of $a-b$ and $D_{c}$, combined with known values of the Young's modulus and Poisson's ratio, indicate a minimum critical nucleation patch size of $\sim 3 \mathrm{~m}$. This minimum value suggests that slip events with a seismic moment $M_{o}$ of at least $\sim 4 \times 10^{10}$ or an $M_{w}$ of at least $\sim 1$, should be expected to be unstable and thus result in earthquakes, not slow slip events.

Acknowledgments We thank the DFDP-1 Alpine Fault team lead by Rupert Sutherland, John Townend, and Virginia Toy. Jim Evans and an anonymous reviewer provided helpful and constructive comments that improved this manuscript. This work was supported by Deutsche Forschungsgemeinschaft grant DFG KO2108/14-1 to A.J.K. 
Open Access This article is distributed under the terms of the Creative Commons Attribution License which permits any use, distribution, and reproduction in any medium, provided the original author(s) and the source are credited.

\section{References}

Beavan J, Moore M, Pearson C, Henderson M, Parsons B, Bourne S, England P, Walcott D, Blick G, Darby D, Hodgkinson K (1999) Crustal deformation during 1994-1998 due to oblique continental collision in the central Southern Alps, New Zealand, and implications for seismic potential of the Alpine fault. J Geophys Res 104:25233-25255

Beavan J, Ellis S, Wallace L, Denys P (2007). Kinematic constraints from GPS on oblique convergence of the Pacific and Australian plates, central South Island, New Zealand. In: Okaya D, Stern T, Davey F (eds) A continental plate boundary: Tectonics at South Island, New Zealand. Geophys Mon Ser 175:75-94, AGU, Washington. doi:10.1029/175GM05

Berryman KR, Cochran UA, Clark KJ, Biasi GP, Langridge RM, Villamor P (2012) Major earthquakes occur regularly on an isolated plate boundary fault. Science 336:1690-1693. doi:10.1126/ science. 1218959

Blanpied ML, Marone CJ, Lockner DA, Byerlee JD, King DP (1998) Quantitative measure of the variation in fault rheology due to fluid-rock interactions. J Geophys Res 103:9691-9712

Boulton C, Moore DE, Lockner DA, Toy VG, Townend J, Sutherland R (2014) Frictional properties of exhumed fault gouges in DFDP-1 cores, Alpine Fault, New Zealand. Geophys Res Lett 41:356-362. doi:10.1002/2013GL058236

Brace WF, Byerlee JD (1966) Stick-slip as a mechanism for earthquakes. Science 153:990-992

Bull WB (1996) Prehistorical earthquakes on the Alpine Fault, New Zealand. J Geophys Res 101(B3):6037-6050

Byrne DE, Davis DM, Sykes LR (1988) Loci and maximum size of thrust earthquakes and the mechanics of the shallow region of subduction zones. Tectonics 7:833-857

Carpenter BM, Saffer DM, Marone C (2012) Frictional properties and sliding stability of the San Andreas fault from deep drill core. Geology 40:759-762. doi:10.1130/G33007.1

Carpenter BM, Kitajima H, Sutherland R, Townend J, Toy VG, Saffer DM (2014) Hydraulic and acoustic properties of the active Alpine Fault, New Zealand: laboratory measurements on DFDP-1 drill core. Earth Planet Sci Lett 390:45-51. doi:10.1016/j. epsl.2013.12.023

Chamberlain CJ, Shelly DR, Townend J, Stern T (2014) Low-frequency earthquakes reveal punctuated slow slip on the deep extent of the Alpine Fault, New Zealand. Geochem Geophys Geosyst 15:2984-2999. doi:10.1002/2014GC005436

Collettini C, Niemeijer A, Viti C, Marone C (2009) Fault zone fabric and fault weakness. Nature 462:907-910. doi:10.1038/ nature 08585

Cooper AF, Norris RJ (1994) Anatomy, structural evolution, and slip rate of a plate-boundary thrust: the Alpine fault at Gaunt Creek, Westland, New Zealand. Geol Soc Am Bull 106:627-633

De Pascale GP, Langridge RM (2012) New on-fault evidence for a great earthquake in A.D. 1717, central Alpine Fault, New Zealand. Geology 40:791-794. doi:10.1130/G33363.1

den Hartog SAM, Spiers CJ (2013) Influence of subduction zone conditions and gouge composition on frictional slip stability of megathrust faults. Tectonophysics 600:75-90. doi:10.1016/j. tecto.2012.11.06

Dieterich JH (1979) Modeling of rock friction 1. Experimental results and constitutive equations. J Geophys Res 84:2161-2168
Dieterich JH, (1981) Constitutive properties of faults with simulated gouge. In: Carter NL, Friedman M, Logan JM, Stearns DW (eds) Mechanical behavior of crustal rocks. Geophys Mon Ser 24:102120, AGU, Washington

Dieterich JH, Kilgore B (1994) Direct observation of frictional contacts: new insights for state-dependent properties. Pure Appl Geophys 143:283-302

Handin J (1969) On the Coulomb-Mohr failure criterion. J Geophys Res 74:5343-5348

Hyndman RD, Yamano M, Oleskevich DA (1997) The seismogenic zone of subduction thrust faults. Isl Arc 6:244-260

Ide S, Beroza GC, Shelly DR, Uchide T (2007) A scaling law for slow earthquakes. Nature 447:76-79. doi:10.1038/nature05780

Ikari MJ, Saffer DM, Marone C (2009) Frictional and hydrologic properties of clay-rich fault gouge. J Geophys Res 114:B05409. doi: $10.1029 / 2008$ JB006089

Ikari MJ, Niemeijer AR, Marone C (2011) The role of fault zone fabric and lithification state on frictional strength, constitutive behavior, and deformation microstructure. J Geophys Res 116:B08404. doi:10.1029/2011JB008264

Ikari MJ, Niemeijer AR, Spiers CJ, Kopf AJ, Saffer DM (2013) Experimental evidence linking slip instability with seafloor lithology and topography at the Costa Rica convergent margin. Geology 41:891-894. doi:10.1130/G33956.1

Ikari MJ, Carpenter BM, Kopf AJ, Marone C (2014) Frictional strength, rate-dependence, and healing in DFDP-1 borehole samples from the Alpine Fault, New Zealand. Tectonophysics 630:18. doi:10.1016/j.tecto.2014.05.005

Koons PO (1987) Some thermal and mechanical consequences of rapid uplift: an example from the southern Alps, New Zealand. Earth Planet Sci Lett 86:307-319

Leitner B, Eberhart-Phillips D, Anderson H, Nabelek JH (2001) A focused look at the Alpine fault, New Zealand: seismicity, focal mechanisms, and stress observations. J Geophys Res 106:2193-2220

Little TA, Cox S, Vry JK, Batt G (2005) Variations in exhumation level and uplift rate along the oblique-slip Alpine Fault, central Southern Alps, New Zealand. Geol Soc Am Bull 117(5-6):707723. doi:10.1130/B25500.1

Lockner DA, Morrow C, Moore D, Hickman S (2011) Low strength of deep San Andreas fault gouge from SAFOD core. Nature 472:82-85. doi:10.1038/nature09927

Ma K-F, Tanaka H, Song S-R, Wang C-Y, Hung J-H, Tsai Y-B, Mori J, Song Y-F, Yeh E-C, Soh W, Sone H, Kuo L-W, Wu H-Y (2006) Slip zone and energetics of a large earthquake from the Taiwan Chelungpu-fault Drilling Project. Nature 444:473-476. doi:10.1038/nature05253

Marone C (1998) Laboratory-derived friction laws and their application to seismic faulting. Ann Rev Earth Planet Sci 26:643-696

Marone C, Kilgore B (1993) Scaling of the critical slip distance for seismic faulting with shear strain in fault zones. Nature 362:618-621

Marone C, Scholz CH (1988) The depth of seismic faulting and the upper transition from stable to unstable slip regimes. Geophys Res Lett 15:621-624

Norris RJ, Cooper AF (2000) Late Quaternary slip rates and slip partitioning on the Alpine Fault, New Zealand. J Struct Geol 23:507-520

Ohnaka M (2000) A physical scaling relation between the size of an earthquake and its nucleation zone size. Pure Appl Geophys 157:2259-2282

Peng Z, Gomberg J (2010) An integrated perspective of the continuum between earthquakes and slow-slip phenomena. Nat Geosci 3:599-607. doi:10.1038/NGEO940

Reinen LA, Weeks JD (1993) Determination of rock friction constitutive parameters using an iterative least-squares inversion method. J Geophys Res 98:15937-15950 
Saffer DM, Marone C (2003) Comparison of smectite- and illite-rich gouge frictional properties: application to the updip limit of the seismogenic zone along subduction megathrusts. Earth Planet Sci Lett 215:219-235

Saffer DM, McKiernan AW, Lockner DA (2012) Effects of smectite to illite transformation on the frictional strength and sliding stability of intact marine mudstones. Geophys Res Lett 39:L11304. doi:10.1029/2012GL051761

Scholz CH (1998) Earthquakes and friction laws. Nature 391:37-42

Scholz CH (2002) The mechanics of earthquakes and faulting, 2nd edn. Cambridge Press, New York

Sibson RH, White SH, Atkinson BK (1981) Structure and distribution of fault rocks in the Alpine Fault Zone, New Zealand. Geol Soc London Spec Pub 9:197-210. doi:10.1144/GSL. SP.1981.009.01.18

Sutherland R, Berryman K, Norris R (2006) Quaternary slip rate and geomorphology of the Alpine fault: implications for kinematics and seismic hazard in southwest New Zealand. Geol Soc Am Bull 118:464-474. doi:10.1130/B25627.1

Sutherland R, Eberhart-Phillips D, Harris RA, Stern T, Beavan J, Ellis S, Henrys S, Cox S, Norris RJ, Berryman KR, Townend J, Bannister S, Pettinga J, Leitner B, Wallace L, Little TA, Cooper AF, Yetton M, Stirling M (2007). Do great earthquakes occur on the Alpine Fault in central South Island, New Zealand? In: Okaya D, Stern T, Davey F (eds) A continental plate boundary: tectonics at South Island, New Zealand. Geophys Mon Ser 175:235-251, AGU, Washington. doi:10.1029/175GM12

Sutherland R, Toy VG, Townend J, Cox SC, Eccles JD, Faulkner DR, Prior DJ, Norris RJ, Mariani E, Boulton C, Carpenter BM, Menzies CD, Little TA, Hasting M, De Pascale GP, Langridge RM,
Scott HR, Lindroos ZR, Fleming B, Kopf AJ (2012) Drilling reveals fluid control on architecture and rupture of the Alpine Fault, New Zealand. Geology 40:1143-1146. doi:10.1130/G33614.1

Tobin HJ, Kinoshita M (2006) NanTroSEIZE: the IODP Nankai Trough seismogenic zone experiment. Sci Drill 2:23-27. doi:10.2204/iodp.sd.2.06.2006

Townend J, Sutherland R, Toy V (2009) Deep Fault Drilling ProjectAlpine Fault, New Zealand. Sci Drill 8:75-82. doi:10.2204/iodp. sd.8.12.2009

Townend J, Sutherland R, Toy VG, Eccles JD, Boulton C, Cox SC, McNamara D (2013) Late-interseismic state of a continental plate-bounding fault: petrophysical results from DFDP-1 wireline logging and core analysis, Alpine Fault, New Zealand. Geochem Geophys Geosyst 14:3801-3820. doi:10.1002/ggge.20236

Toy VG, Boulton CJ, Sutherland R, Townend J, Norris RJ, Little TA, Prior, DJ, Mariani E, Faulkner D, Menzies CD, Scott H, Carpenter BM, (2014) Fault rock lithologies and architecture of the central Alpine Fault, New Zealand, revealed by DFDP-1 drilling. Lithos (in review)

Wallace LM, Beavan J, McCaffrey R, Berryman K, Denys P (2007) Balancing the plate motion budget in the South Island, New Zealand using GPS, geological and seismological data. Geophys J Int 168:332-352. doi:10.1111/j.1365-246X.03183.x

Wech AG, Boese CM, Stern TA, Townend J (2012) Tectonic tremor and deep slow slip on the Alpine Fault. Geophys Res Lett 39:L10303. doi:10.1029/2012GL051751

Zoback M, Hickman S, Ellsworth W, SAFOD Science Team (2011) Scientific drilling into the San Andreas fault zone-an overview of SAFOD's first five years. Sci Drill 11:14-28. doi:10.2204/ iodp.sd.11.02.2011 